\title{
Dekonstruktiewe lesing van 'n teks
}

\section{CS de Beer}

\begin{abstract}
Deconstructive reading of a text

Deconstructive reading must be considered as a strategy exploring the paths of thinking. In this strategy emphasis is laid on (1) the textuality of the text which offers a point outside the logocentric totality from where logocentrism can deconstructively be articulated; (2) the suspended position of the author who disappears behind the text, not dominating it anymore; (3) the senselessness of the problem of reference since the text is infinitely disseminated in its continuous undecidable allusion to other texts (4) the re-interpretation of interpretation which is directed towards the preoccupied dissimulation of the texture of the text itself which amounts to writing as the production of a signifying structure that alludes to nothing but a labyrinth of the path of thinking challenging thinking to venture upon it.
\end{abstract}

In die gewaardeerde versoek om hierdie bydrae te lewer, gaan dit om die vraag: Wat beteken dit om 'n teks (in hierdie geval die Bybel) te interpreteer, dus om tot die verstaan van 'n teks, hierdie teks, te kom? Meer nog: Hoe moet interpretasie geïnterpreteer word? Of, wat word verstaan onder hermeneutiek? Of, hoe word geïnterpreteer in terme van dit wat dekonstruksie genoem word? Is dit moontlik dat hier 'n verstaanstrategie ontwerp is wat tot nuwe insig kan lei? Wat belangrik is, is die manier waarop ' $n$ teks benader word of die wyse waarop daar met die teks omgegaan word. Die vraag na metode kom na vore! Wat word met 'metode' bedoel? Gaan dit om 'n poging om reëls vas te stel waarvolgens ' $n$ teks bestudeer kan of/moet word? Of om nog nader te kom aan die idioom van ons dag: Wat beteken dit om ' $n$ teks te lees; hoe lees ons tekste; wat behels en wat veronderstel hierdie leeshandeling, ensovoorts? Volgens watter riglyne word daar binne die dekonstruksie gedink oor interpretasie, of oor die leeshandeling? Die dekonstruktiewe leeshandeling, gerig op 'n teks, behels 'n spesifieke interpretasieteorie, asook teksteorie. Ons het te doen met interpretasie in aksie; met die beoefening van die leeskuns.

Is daar bevoorregte enkelinge, of groepe, wat beter as ander gekwalifiseerd is om sekere tekste te lees, of sekere tekste korrek te lees, en die regte gevolgtrekkings te bereik? Weet diesulkes moontlik by voorbaat 
wat uit ' $n$ teks gehaal kan, of gehaal mag word? Of is almal min of meer ewe onkundig oor die oop moontlikhede wat die leeshandeling bied?

Teen hierdie agtergrond is dit begryplik dat daar ' $n$ verskeidenheid leesstrategieë mettertyd na vore gekom het waarvan dekonstruksie een van die mees resente is. Soos dit met alle menslike aktiwiteite gesteld is, is dit ook die geval met die leeshandeling: Sowel die handeling as die uitkoms daarvan word deur bepaalde filosofies-metafisiese vooronderstellinge beïnvloed. Metode is so ' $n$ aktiwiteit - die metode wat aangewend word, word bepaal deur die filosofie wat eksplisiet, maar veral ook implisiet (en dit is gevaarliker, omdat baie graag dink dat hulle nie ' $n$ filosofie het nie en nie besef dat dit verdring word nie en hulle dus onbewustelik beïnloed is nie) aangehang word. Dit geld veral vir Suid-Afrika waar almal - opvoedkundiges, teoloë, wetenskaplikes, politici, ensovoorts - hulleself en die volk so suiwer as moontlik wil beskerm teen die filosofie sonder om te besef hoe filosofies deurdrenk, op hoe ' $n$ distorte wyse ook al, hierdie samelewing tog is.

Op hierdie manier reflekteer die hermeneutiese metode, soos die positivistiese metode en vele ander, 'n baie spesifieke filosofiese stellingname. Sodanige stellingname gee gewoonlik aanleiding tot sekere opvattinge oor die korrektheid, suiwerhied, waarheid, geldigheid, betekenis, ensovoorts van kennis waartoe die toegang bepaal word, en dikwels op 'n baie rigiede wyse, deur' $n$ bepaalde metode. Wanneer dit in die metode dan spesifiek gaan oor die lees van 'n teks, impliseer dit die moontlikheid van 'n korrekte of verkeerde leeswyse, geldige of ongeldige gevolgtrekkings, ensovoorts. Hierdie oordele word egter dikwels nie soseer gevel op grond van die spesifieke metode wat as sodanig aangewend word nie, maar op grond van die spesifieke filosofie (resp metafisika) agter die metode wat dikwels verdring is of verswyg word (op eerlike of oneerlike wyse).

In hierdie verband is dekonstruksie belangrik, omdat dit enersyds hierdie filosofiese geladenheid van menslike aktiwiteite en oortuiginge, en baie spesifiek die bepalende aard daarvan, in sy kern aanspreek, maar andersyds ook heel spesifiek die metafisiese geladenheid van teorieë oor leesmetodes adresseer. Daar word hoë verwagtinge van die metode gekoester. Dit moet insig in die waarheid bring; deur die metode moet die werklikheid ontsluit word; die korrekte metode sou lei tot universele en algemeen aanvaarde waarheid. Op dié wyse word hoë verwagtinge van 'n bepaalde metode gekoester. Hiervolgens sou 'n sekere metode van tekslesing die leser uitbring by die waarheid in die teks en ander nie. 
Daar word uit die oog verloor dat elke metodologiese benadering reeds veronderstel dat ons weet wat ' $n$ teks is, watter betekenis in die teks verskuil lê of selfs aanvaar dat daar betekenis verskuil lê, dat daar 'n outeur is met sekere en nie ander bedoelinge nie. So sou 'n mens kon voortgaan. Op dié wyse word tekste verplig om te sê wat die leser of groep lesers daarvan eis. Die teks word dus gemanipuleer om nie sy sê te sê nie, maar die leser s'n en heel dikwels op 'n verbasend kollektiefeenstemmige wyse.

Die dekonstruktiewe benadering behels ' $n$ radikale bevraagtekening van die geldigheid van die eksplisiete, of implisiete filosofie en die bepalende aard daarvan met betrekking tot die benadering tot of ontwikkeling van bepaalde metodes. Sekere momente van die dekonstruktiewe benadering, kan hier kortliks by wyse van inleiding en met die oog op oriëntasie na vore gebring word. Dit geskied aan die hand van 'n boeiende opstel met die titel 'La langue et le discours de la mèthode', geskrywe deur een van die belangrikste eksponente van hierdie rigting, naamlik Jacques Derrida.

- Elke metode het 'n reeks wesenlike predikate waarsonder die metode nie metode kan wees nie.

- Daar is geen metode, etimologies gesien (methodeía), sonder die gedagte van onderweg wees, sonder koers, opeenvolging, gang, ensovoorts nie.

- Elke metode impliseer algemene reëls, tegnieke van herhaling, steeds terugkerende prosedures wat toegepas moet word, en daar is rede om te dink dat ' $n$ onherhaalbare metode sonder waarde is.

- Deur hierdie mag van herhaling behou die metode die mag van die geskiedenis en die mag van 'n sekere historisiteit wat verband hou met die uitwissing van 'n enkele gebeurtenis.

- Daar is ' $n$ provokerende paradoks: Historiese en individuele gebeurtenisse lei tot die paradoksale geskiedenis van die metode: geskiedenis - nie-geskiedenis, herhaling - nie-herhaling.

- Die woord 'diskoers' verdubbel dieselfde probleem: Metode is 'n sekere manier van reëling van die koers, die loop, die trajek, die roete, dit wil sê van die diskoers (discurrer: hardloop van hier, van daar; die maak van 'n ekskursie, afwyking en dan ... gaan voort in spreke, volg 'n rooster of program van spreke).

- Diskursiwiteit is 'n soort 'geroosterde' of 'geprogrammeerde' spreke, sodanig dat diskoers oor metode net sowel diskoers oor diskoers of metode oor metode kon wees. 
- Diskoers oor metode kan buite konteks laat dink aan diskoers inherent aan metode, diskoers as metode; diskoers is 'n metodiese weg, 'n gereguleerde voortgang.

- Elke metode is diskoers, hoewel verkilde diskoers, deur en deur geweefde diskoers.

- Die weg kan gesien word as diskoers, of as denke; dieselfde woord 'denke' dui op die weg en op die diskoers.

- Die diskoers oor die metode kan ook gesien word as reëls wat uitgewerk word as rigtinggewing aan die gees.

- Diskoers, metafoor, retoriek, metode is alles gekonstitueer op die grondslag en onder heerskappy van denke wat self onderweg is en as weg bepaal is.

- Denke bewaar en handhaaf 'n verhouding met topologie en verplasing binne die ruimtelikheid van die teks.

- Daar is altyd 'n corpus van denke, diskoers en poësie waarbinne die weg nie reduseerbaar is nie, maar oop bly.

Die indeks vir hierdie denkbeelde oor metode kry ons uit die gedig van Parmenides. Dit is die gedig van die pad of weg.

In die gedig merk die godin op dat daar slegs twee weë vir die poesië is: Een waarvan daar ver weggebly moet word ten einde slegs by die enkele een betrokke te wees wat bly en waarvan ons kan sê dat dit is - die syn. Die ander een verdeel in twee: Van een kan gesê word dat dit die nie-syn is; die ander is dié van sterflikes met 'n dubbele hoof, dié wat sowel syn as nie-syn laat wees en betrokke is op'n doolhof as weg, 'n weg waarvan die sin verander, ' $n$ weg wat terugkom of laat terugkom op sy spoor, 'n omgekeerde sin dus. Daar kan veel gesê word oor metode in sy verhouding tot die doolhof van 'n teks. Ons weet dat die mees beslissende vraag aan die begin van die filosofie, in elk geval, dié van die denke is, van syn en nie-syn. Probeer dink oor die wese van die weg sonder die moontlikheid van taal en diskoers. Ons kan nie oor die weg dink sonder iets soos taal en diskoers of teks, of omgekeerd, taal, diskoers of teks sonder iets soos 'n weg nie.

Die weg wat eie is aan die filosofie van Heidegger, is 'n denke van die weg as denke, van die denke as weg, van taal (Sprache) as weg (weg in die sin van beweging, dit wil sê as onderweg wees). Derrida vereenselwig hom met wat Heidegger opeis vir die denke van die weg en die weg van die denke, naamlik dat dit nie georiënteer is deur 'n bepaalde gerigtheid of bepaalde reëls of deur 'n rigiede metode nie. Die metode is hier 'n beperkende faktor op die wegkarakter van die denke. 'Die epog van die metode, van die filosofie van die metode, as metode, van 
die groot metodologie, dit wil sê van Descartes tot Hegel, is die epog waarin die weg van die denke, die wegkarakter van die denke op erg beperkende wyse bepaal is as die tegnologiese prosedure van moderniteit, binne die heerskappy van die voorstelling, van die verhouding subjek-objek, van die bemeestering en ondervraging van die natuur' (Derrida 1983: 44). In hierdie verband sal dit ook goed wees om die artikel van Heidegger (1985) te lees waarby Derrida aansluiting vind vir sy besinning oor metode.

Wat is eie aan denkweg in sy verskil van metode? Wat is dit wat maak dat denkweg metode word? Hoe gebeur dit dat weg gedissimuleer en geperverteer word tot metode? Die metodewording van die denke is toe te skrywe aan die twee denkers van bewussyn en representasie, naamlik Descartes en Hegel. Metode is ' $n$ reël; dit dereguleer die weg met betrekking tot dit wat eie daaraan is en dit onteien die weg ten aansien van sy wese.

Dit wat die wegkarakter van die denke ondenkbaar maak, is die oorheersende houding van voorstelling, van representasie, van voorstellende, objektiverende denke, wat van die syn 'n objek vir die subjek van wetenskap en tegniek maak. Die definisie van die metodiese prosedure is dat denke metode word deur die ding as objek na te jaag, te agtervolg, op te spoor, te verlei. Die metode word 'n soort tegnologisering van die denke. Die kwaad is geleë in die metode- en tegnologiewording van die weg, van die op-weg-synde denke, van die weg-karakter van die denke. Dit wat eie is aan die weg, naamlik die op-wegwees, word 'n slagoffer van ' $n$ verstelling - die verplasing, defigurasie, 'n pervertering - deur die voorstelling, die representasie deur die subjek van representasie in die tegnologiese bemeestering van die objek.

Die benadering tot ' $n$ teks ten einde reg daaraan te laat geskied, kan teen hierdie agtergrond nooit dié wees van 'n metodologie nie, maar wel dié van die onder-weg-wees van die denke. Uiteraard beantwoord die tekstualiteit van die teks, die tekswees van die teks soos dit binne die dekonstruktiewe benadering gesien word, geheel en al hieraan. Teks is nie 'n entiteit waarvan subjekte voorstellings kan maak nie, maar deur sy ruimtelikheid bied die tekstualiteit van die teks oopheid vir die speelse beweging van die denke.

Die vraagstelling met betrekking tot die metodologiese wat wel hier aan die orde is, word kernagtig geformuleer in 'n teks van Jacques Derrida, naamlik Dissemination. Hierdie formulering kan gesien word as ' $n$ samevatting van ' $n$ bepaalde diskoers oor interpretasie, ' $n$ soort handves vir dekonstruktiewe interpretasie en toon duidelik waarom 
hier nie sprake kan wees van ' $n$ metode in die gewone sin van die woord nie, maar eerder van 'n weg of selfs weë wat geopen word deur die leeshandeling:

A text is not a text unless it hides from the first comer, from the first glance, the law of its composition and the rules of its game. A text remains, moreover, forever imperceptible. Its law and its rules are not, however, harbored in the inaccessibility of a secret; it is simply that they can never be booked, in the present, into anything that could rigorously be called a perception.

And hence, perpetually and essentially, they run the risk of being definitively lost. Who will ever know of such disappearances?

The dissimulation of the woven texture can in any case take centuries to undo its web: a web that envelops a web, undoing the web for centuries; reconstituting it too as an organism, indefinitely regenerating its own tissue behind the cutting trace, the decision of each reading. There is always a surprise in store for the anatomy or physiology of any criticism that might think it had mastered the game, surveyed all the threads at once, deluding itself, too, in wanting to look at the text without touching it, without laying a hand on the 'object', without risking - which is the only chance of entering into the game, by getting a few fingers caught - the addition of some new thread. Adding, here, is nothing other than giving to read. One must manage to think this out: that it is not a question of embroidering upon a text, unless one consider that to know how to embroider still means to have the ability to follow the given thread. That is, if you follow me, the hidden thread. If reading and writing are one, as is easily thought these days, if reading is writing, this oneness designates neither undifferentiated (con)fusion nor identity at perfect rest; the is that couples reading with writing must rip apart.

One must then, in a single gesture, but doubled, read and write. And that person would have understood nothing of the game who, at this ( $d u$ coup), would feel himself authorized merely to add on; that is, to add any old thing. He would add nothing: the seam wouldn't hold. Reciprocally, he who through 'methodological prudence', 'norms of objectivity', or 'safeguards of knowledge' would refrain from committing anything of himself, would not read at all. The same foolishness, the same sterility, obtains in the 
'not serious' as in the 'serious'. The reading or writing supplement must be rigorously prescribed, but by the necessities of a game, by the logic of play, signs to which the system of all textual powers must be accorded and attuned (Derrida 1981: 63-64).

Uit hierdie samevatting is daar enkele uiters belangrike aspekte van 'n teks en die lees daarvan wat kortliks vir oorweging aangestip kan word:

- 'n Teks verberg iets; dit bly vir altyd onwaarneembaar.

- As geweefde tekstuur is die ontrafeling, herkonstituering en regenerasie daarvan ' $n$ voortgaande beslissing van elke lesing.

- Die anatomie en filosofie van enige kritiek wat aanspraak maak op bemeestering, kan altyd 'n verrassing te wagte wees.

- Elke toevoeging tot die netwerk kom op niks anders neer nie as om iets verder te lese te gee.

- Die is waarvolgens beweer word dat lesing skriftuur is, moet weggeskeur word en dan moet daar in 'n enkele gebaar, maar verdubbel, gelees en geskryf word.

- Wie deur 'metodologiese verstandigheid', 'norme van objektiwiteit' en 'waarborge van kennis' daarvan terugdeins om homself in sy omgang met die teks, op die spel te plaas, is geen leser nie.

- Dieselfde dwaasheid en steriliteit geld eweseer vir die 'ernstige' en die 'nie-ernstige'.

- Lees- en skryf-supplement moet op gestrenge wyse voorgeskrywe word, dog in terme van die noodsaaklike vereistes van die spel.

Met so 'n voorwoord tot dekonstruksie, wat terselfdertyd 'n aanduiding is van die wese van die grammatologie, kan die beslissende vrae aangaande interpretasie rondom die volgende temas saamgevat word:

- Interpretasieteorie is ' $n$ leesteorie wat nou verbonde is aan 'n teksteorie met die klem op die tekstualiteit van die teks.

- In samehang met die dimensie van die interlokuteurs en die probleem van kommunikasie wat daarmee saamhang, moet die opgeskorte plek van die outeur in die interpretasie van die teks nagegaan word.

- Hoe moet die probleem van verwysing op die vlak van die teks gestel word en waarna word verwys?

- Die herbeskrywing van die taak van interpretasie in die lig van die herinterpretasie van interpretasie lyk noodsaaklik. 
Die bespreking van hierdie temas aan die hand van die dekonstruktiewe benadering behoort dit enersyds duidelik af te grens van die hermeneutiese teorie en die filosofiese veronderstellinge daarvan. Andersyds kan dit belangrike gedagtes na vore bring teen die aanvaarde en gevestigde inhoude waartoe die hermeneutiek van die Bybel lei.

\section{DIE TEKSTUALITEIT VAN DIE TEKS}

Die teks as translinguistiese teorie het op verskillende maniere in die jongste tyd aandag gekry met besondere betekenisverskuiwinge wat plaasgevind het. In die tradisionele sin van die woord is teks die naam van 'n werk vir sover dit gevul is met sin, met ware en definitiewe sin. Dit het 'n wetenskaplike instrument geword wat op gesaghebbende wyse die leesreëls wat vir ewig moet geld, definieer. Hierdie klassieke, institusionele opvatting van die teks is duidelik verbind aan ' $n$ bepaalde metafisika van die waarheid.

Soos die eed egtheid verleen aan die spreke, so verleen die teks egtheid aan die geskrif: sy oorsprong, sy sin en sy waarheid. Hoeveel stryde word nie al vir eeue gevoer oor die waarheid nie en hoeveel gevegte was daar nie namens een betekenis teen ' $n$ ander nie? Hoeveel angs was daar nie oor die onsekerhede oor tekens en betekenis nie, en hoeveel reëls is nie opgestel om dwalinge te besweer nie. Dit is hierdie selfde geskiedenis wat soms bloedig, maar altyd bitter verloop het wat waarheid, teken en teks aan mekaar verbind het.

Dit is terselfdertyd hierdie krisis wat in die vorige eeu deur die werk van die 'hamerende' Nietzsche die metafisika van die waarheid geskud het, wat ook in hierdie eeu die teorie van die taal en die literatuur oopgebreek het deur'n ideologie-kritiek van die teken. Die gevolg was dat 'n nuwe teksopvatting die heersende verouderde teksopvatting vervang het. Onder die invloed van die linguistiek is daar begin met die uitspreek van 'n kritiek van die teken wat gelei het tot die ontwikkeling van die genoemde nuwe teorie van die teks. Die linguistiek het daartoe bygedra dat die maatstaf van waarheid vervang is deur dje maatstaf van geldigheid. Dit wil sê, dat die taal onttrek is aan die sanksies van die inhoud, en die rykdom, subtiliteit en selfs die oneindige toutologiese transformasies van die diskoers ontgin word. Terselfdertyd het die analise van die literêre diskoers onder die invloed van die semiologie na vore gekom. Die linguistiek het by die volsin en die eenhede waaruit dit saamgestel is (sintagmas, morfeme, foneme), tot stilstand 
gekom. Maar wat dan van die res? Wat is die strukturele eenhede vir die diskoers? Die literère semiotiek het behoefte gehad aan ' $n$ diskursiewe eenheid wat meer kan wees as die volsin, maar ook daarbinne kan wees, hoewel dit altyd struktureel verskillend daarvan is en wat teks genoem is. Die teks kan saamval met ' $n$ volsin èn ook saamval met 'n hele boek. Dit konstitueer 'n sisteem wat nie noodwendig met die linguistiese sisteem te identifiseer is nie, maar wel in verhouding daarmee staan: ' $n$ verhouding van nabyheid en ooreenkoms.

Hierdie nuwe teksopvatting is nader aan die retoriek as aan die filologie en onderworpe aan die beginsels van die positiewe wetenskap. Die teks word op 'n immanente wyse bestudeer, aangesien elke verwysing na die inhoud en na sosiologiese, psigologiese en historiese bepalinge verbode is. Dit word egter ook van buite bestudeer as ' $n$ blote objek wat onderworpe is aan die ondersoek op ' $n$ afstand van 'n kennende subjek. Wanneer die aanwinste van die linguistiek en die semiologie doelbewus geplaas word binne die nuwe veld van verwysinge wat wesenlik gedefinieer word deur die kommunikasie tussen twee verskillende épistémés, naamlik die dialektiese materialisme (Marx en Engels) en die psigo-arialise (Freud en Lacan) kom daar 'n sogenaamde epistemologiese mutasie na vore. Vir 'n nuwe wetenskap om tot stand te kom, is dit nie voldoende wanneer die verouderde wetenskap slegs verdiep of uitbrei nie; 'n ontmoeting tussen verskillende épistémés is nodig. Hierdie ontmoeting produseer 'n nuwe voorwerp wat iets anders is as ' $n$ nuwe benadering tot ' $n$ ou voorwerp. In sy verskyning word hierdie nuwe voorwerp teks genoem.

Op die vlak van hierdie nuwe opvatting van teks stel Derrida dan ook die vraag na die teks op 'n nuwe wyse. Hy ondervra by voorkeur 'tekste bereken tot die mag twee' (Derrida 1981: 240). Hierdie teksopvatting laat toe dat die vraag na die teks op 'n meer korrekte manier gestel word. Vanuit hierdie gesigspunt word die ontdekking van tekstualiteit moontlik en wel met behulp van die lesing van ' $n$ teks van Mallarmé. Dít wat die Mimique van Mallarmé te lese gee, is 'n teks wat terugkeer na homself.

The Mallarméan fold will always have been not only replication of the tissue but also a repetition-toward-itself of the text that is a refolding, a replying, a supplementary re-marking of the fold (Derrida 1981: 238).

En dit is hierdie selfde gedagte wat lei tot die lesing van Rousseau in Of Grammatology met besondere verwysing na die supplement: 
This theme describes the chain itself, the being-chain of a textual chain, the structure of substitution, the articulation of desire and of language the logic of all conceptual oppositions taken over by Rousseau, and particularly the role and the function, in his system, of the concept of Nature. It tells us in a text what a text is, it tells us in writing what writing is, in Rousseau's writing it tells us Jean-Jacques's desire, etc. If we consider, according to the axial proposition of this essay, that there is nothing outside the text, our ultimate justification would be the following: the concept of the supplement and the theory of writing designate textuality itself in Rousseau's text in an indifinitely multiplied structure - en abyme (in an abyss) - to employ the current phrase. An entire theory of the structural necessity of the abyss will be gradually constituted in our reading; the indefinite process of supplementarity has always already infiltrated presence, always already inscribed there the space of repetition and the splitting of the self. Representation in the abyss of presence is not an accident of presence; the desire of presence is, on the contrary, born from the abyss (the indefinite multiplication) of representation, from the representation of representation, etc. The supplement itself is quite exorbitant, in every sense of the word. Thus Rousseau inscribes textuality in the text (Derrida 1977: 163).

Derrida (1977: 231) erken self dat hierdie keuse vir hom buitensporig is, maar met hierdie keuse respondeer hy op die logosentriese stellingname van die hermeneutiek. Hy soek na'n punt buite die totaliteit van die eeu van die logosentrisme vanwaar die logosentriese epog op beslissende wyse geartikuleer kan word; die fundamentele operasie van die epog, naamlik die onderdrukking van die skriftuur, bepaal kan word; en 'n sekere dekonstruksie van hierdie totaliteit 'n aanvang kan neem. Waar moet daar begin word? Derrida (1977: 162) antwoord:

We must begin wherever we are and the thought of the trace, which cannot take the scent into account, has already taught us that it was impossible to justify a point of departure absolutely. Wherever we are: in a text where we already believe ourselves to be.

Vanuit hierdie oogpunt gesien, is die verskil wat nou diepgaande oorweeg moet word die verskil tussen die uitgewisde tekstualiteit (die 
teks as virtuele betekenis, as mag van die waarheid), en 'n genoteerde tekstualiteit (die teks tot die tweede mag, geformaliseer tot ' $n$ punt waar sy mag om filosofiese konsepte te skud, dié van die logies-matematiese begrip in sy verhouding tot die spekulatiewe rede ver oorskry) (Derrida 1981: 222).

Wat beteken die notering van ' $n$ teks?

1. Dit beteken allereers om 'die ruimtelikheid van die skriftuur' te noteer (Derrida 1981: 235) wat van die boek'die totale ekspansie van die letter' maak (Derrida 1981: 236) en van die teks as non-representatiewe organisasie die veelkernige netwerk van betekenis (Derrida 1981: 177).

Die teks is ten diepste ' $n$ landskap of toneel en die skryfhandeling beteken om op die toneel te bring. Hierdie landskaplike en teatrale is dit wat eintlik Derrida se gedagtes besig hou. Dit is duidelik dat die teatrale nie dié van die teater van representasie is nie, maar juis 'n teatrale wat vertrek vanuit die uitwissing van die motief van presensie. Hierteenoor is die teks in die sin van die hermeneutiek representasie, in die presiese en letterlike sin van die woord (Anwesen van Heidegger). Dit wil sê, tekstuele presensie van betekenis en representasie deur iemand wat doelbewus daargestel is en klop met die mimesis-gedagte van Plato.

Die ruimtelikheid van die skriftuur maak ruimtegewing moontlik in die plek van die uitwissing van die intimiteit van betekenis wat by en in homself bestaan:

Far from replacing the stage as substituting a perfectly maste-ed interiority for the slipping away of a space, this suppleance (addition/representation) implacably retains and repeats the theatrical stage within the book (Derrida 1981: 235).

2. Die tekstualiteit van die teks word verder genoteer deur 'die onreduseerbare oormaat van die sintaktiese oor die semantiese'. Die lesing van Mallarmé, soos deur Derrida uitgevoer, berus geheel en al op die noodsaaklikheid om die volle draagwydte van hierdie oormaat te erken. Die plasing van woorde en die speleffekte daarvan, eerder as die inhoud, is belangrik.

En dit geld vir sy hoof leesprotokolle wat handel oor die supplèment (Rousseau), die pharamakon (Plato) en die hymen (Mallarmé). Dit wat Derrida interesseer, is nooit (soos mens geneig sou wees om te glo) die benutting van die polisemie van hierdie woorde, dus die tematiese of semantiese inhoud daarvan nie. 
Die term polisemie is van hermeneutiese oorsprong en onlosmaaklik deel van die metafisiese vooronderstellinge daarvan. Dit geld eweneens vir die behandeling van die metafoor wat volgens Ricoeur ' $n$ 'miniatuurteks' is. Dit sou sekerlik ' $n$ versoeking wees om in die strik van polisemie te trap en om 'n soort 'Gegensinn der Urworte' in die sin van Freud te konstrueer, of om die spekulatiewe instink van die natuurlike taal bloot te lê, soos Hegel dit gedoen het, met woorde soos Aufhebung, Urteil, Meinen, Beispiel, ensovoorts. Sodanige operasie, indien dit ooit prakties moontlik sou wees, strand op die rekenskap wat gegee word van die spesifiekheid van Mallarmé se teks.

Die woord hymen verskyn, met dieselfde sintaktiese bronne van onbeslisbaarheid, op ' $\mathrm{n}$ min of meer sistematies gehanteerde wyse, in verskeie van Mallarmé se werke. Om mee te begin: die hymen produseer die effek van 'n medium.

At the edge of being, the medium of the hymen never becomes a mere mediation or work of the negative; it outwits and undoes all ontologies, all philosophemes, all manner of dialectics. It outwits them and - as a cloth, a tissue, a medium again - it envelops them, turns them over, and inscribes them (Derrida 1981: 215).

Dit is ' $n$ operasie wat sowel verwarring stig tussen teenoorgesteldes en tussen die teenoorgesteldes 'n staanplek inneem. Wat hier belangrik is, is die tussen, die tussen-in-wees van die hymen. Die hymen neem sy plek in in die 'inter', in die ruimte tussen begeerte en vervulling. Dit wil voorkom of daar sprake kan wees van 'die logika van die hymen' wat Derrida (1981: 212-213) soos volg verwoord:

We are thus moving from the logic of the palisade, which is always, in a sense, 'full', to the logic of the hymen. The hymen, the consummation of differends, the continuity and confusion of the coitus, merges with what it seems to be derived from: the hymen as protective screen, the jewel box of virginity, the vaginal partition, the fine, invisible veil which, in front of the hystera, stands between the inside and outside of a woman, and consequently between desire and fulfillment. It is neither desire nor pleasure but in between the two. Neither future nor present, but between the two. It is the hymen that desire dreams of piercing, of bursting, in an act of violence that is (at 
the same time or somewhere between) love and murder. If either one did take place, there would be no hymen. But neither would there simply be a hymen in (case events go) no place. With all the undecidability of its meaning, the hymen only takes place when it doesn't take place, when nothing really happens, when there is an all-consuming consummation without violence, or a violence without blows, or a blow without marks, a mark without a mark (a margin), etc, when the veil is, without being, torn, for example when one is made to die or come laughing.

Yunu designates a fine, filmy membrane enveloping certain bodily organs; for example, says Aristotle, the heart or the intestines. It is also the cartilage in certain fish, the wings of certain insects (bees, wasps and ants, which are called hymenoptera), the foot membranes in certain birds (the hymenopoda), a white pellicle over the eyes of certain birds, the sheath encasing the seed or bean of plants. A tissue on which so many bodily metaphors are written.

Dit is in die lig hiervan dat Derrida (1981: 220) oor die woord hymen soos volg opmerk: 'What counts here is not the lexical richness, the semantic infiniteness of a word.... What counts here is the formal or syntactical praxis that composes and decomposes.'

Dit is die rede waarom, teenoorgesteld aan die semantisme van Humboldiaanse oorsprong, die analise van die Mallarméaanse teks nie stop by 'n kundige eksploitasie van die polisemie van die woord hymen nie, maar daaroor heenwys na sekere sinkategoreme soos byvoorbeeld 'tussen' (entre). Hieroor skrywe Derrida (1981: 222):

One no longer even has the authority to say that 'between' is a purely syntactic function. Through the re-making of its semantic void, it in fact begins to signify. Its semantic void signifies, but it signifies spacing and articulation; it has as its meaning the possibility of syntax; it orders the play of meaning.

Dit sou vals wees om te beklemtoon dat die grens tussen hermeneutiek en grammatologie tussen sin en on-sin deurloop. Vir die volheid van sin, vir die teenwoordigheid van 'n vol stem, word daar nie eenvoudig ' $n$ afwesigheid van $\sin$, as die ekwivalent van nie-sin, gesubstitueer nie. Die sinkategoreem is onmisbaar vir die verstaan van die teks van Mallarmé; eerder as om dit te interpreteer as onvolledige 'betekenisgewing' in lyn met die metafisika wat strek vanaf 
Plato tot Husserl, moet oorweging daaraan geskenk word dat die sinkategoreem 'tussen' 'n 'kwasie-leë semantiek' as sinsinhoud het wat 'die verhouding van ruimtegewing, artikulasie, interval, ensovoorts aandui' (Derrida 1981: 222 noot).

Die oormaat van die sintaktiese deurbreek die hermeneutiese horison wat Derrida metafories aandui met 'omraming', en open in die rigting van ' $n$ ander tipe ruimtelikheid. Dit is hierdie verskil wat maak dat disseminasie onreduseerbaar is tot polisemie. ' $n$ Duidelike uiteensetting word op die volgende wyse verskaf:

The concept of polysemy thus belongs within the confines of explanation, within the explication or enumeration, in the present, of meaning. It belongs to the attending discourse. Its style is that of the representative surface. It forgets that its horizon is framed. The difference between discursive polysemy and textual dissemination is precisely difference itself, 'an implacable difference'. This difference is of course indispensable to the production of meaning (and that is why between polysemy and dissemination the difference is very slight). But to the extent that meaning presents itself, gathers itself together, says itself, and is able to stand there, it erases difference and casts it aside. Structure the differential is a necessary condition for the semantic, but the semantic is not itself, in itself, structural. The seminal, on the contrary, disseminates itself without ever having been itself and without coming back to itself. Its very engagement in division, its involvement in its own multiplication, which is always carried out at a loss and unto death, is what constitutes it as such in its living proliferation. It exists in number (Derrida 1981: 351).

Daar moet noukeurig gelet word op die delikate, maar belangrike verskil (différence) tussen diskursiewe polisemie en tekstuele disseminasie.

3. Op hierdie punt kom die term 'produksie' na vore. Die teks, soos Derrida dit verstaan, is produksie in ' $n$ heel spesifieke sin. Hoewel daar rede sou wees om hierdie kategorie te wantrou wat in baie kontekste en vir baie lank funksioneer as aanvullende bevestiging van die mees klassieke metafisika, kan die ekonomie van hierdie konsep nie gemaak word nie. Die produksie, of eerder, die teks as produksie, kom na vore vanaf daardie oomblik dat daar wegbeweeg word 
van die idealiteit van sin met behulp waarvan die teks volgens die hermeneutiek gedefinieer word. Hier weer, soos by die vraag na polisemie, is die skeiding of grens moeilik om te bepaal. Dit loop tussen die Platoniese mimesis en die Mallarméaanse mimiek, tussen die idee en die luister, dit wil sê tussen 'n sekere idealisme van sin en ' $n$ materialisme van die idee, tussen die deursigtigheid van sin en die 'onder glas' van Mallarmé 'a glorious lie ... that art attempts to render true, and for that it must ... put it under glass' (Derrida 1981: 233). Daarom moet die tekstuele doolhof, gepaneel met spieëls (Derrida 1981: 195), verstaan word as 'n aktiewe operasie van verplasing waardeur aan die gesag van die waarheid ontsnap word.

Die différance, 'n begrip uit die ekonomie, produseer duidelik effekte in die teks wat allereers daartoe dwing dat die realiteit van die teks gedink word in terme van werk en operasie. Dit beteken nie dat die teks performatief in Austin se sin van die woord sou wees nie (by Austin soos by die ander Angel-Saksiese filosowe word die performatiwiteit evident gemaak op die grondslag van 'n teorie van die diskoers). Om die 'onder glas', op 'n nie-idealistiese wyse te verstaan, moet die verglasing, die produksie van die glas, nie buite rekening gelaat word nie.

This production does not consist - any more than does the hymen - simply in unveiling, revealing, presenting; nor in concealing or causing to disappear all at once; nor in creating, inventing or inaugurating. If the structure of this glass has anything in common with that of the hymen, then its role is to dislocate all these oppositions. The glass must be read as a text, or, ... as an undecidable 'signifier' (Derrida 1981: 233).

4. Die term teks, soos Derrida dit gebruik, is onskeibaar van die term 'behoort'. Tekste wat ons lees, verwys sonder einde na ander tekste. Dit is binne hierdie behoort, wat ten diepste niks anders is as die sisteem van al die verskille nie, dat die opdeling beoefen kan word. Dis is opdeling wat nie gemaak word vanuit die gesigspunt van outeurs nie, maar volgens ander maatstawwe. Alles gebeur asof die hermeneutiek en die grammatologie mekaar op hierdie punt moet verstaan. Maar daar moet geen illusies wees nie: Dieselfde woord verberg werklikhede by die twee opvattinge wat sterk van mekaar verskil. Volgens die hermeneutiek is behoort in laaste instansie gefundeer op die voorreg van te kan luister. Ons behoort tot tekste wat vóór ons is vir sover ons hulle toelaat om ons tot antwoorde uit 
te daag. Volgens die grammatologie bevind ons ons binne die teks soos mens opgeneem is in die vesels van ' $n$ weefsel. Die term teks is 'n metafoor: weefsel, netwerk, plot, ensovoorts. Dit wat geweef word, behoort nie tot ons nie, maar ons behoort daartoe. Hierdie behoort, bevat egter niks van die intimiteit van vertoef nie. Indien om te lees, beteken om in die teks te wees, kies die leser nogtans nie sy verblyf daar nie. Behoort, soos Derrida dit verstaan, is onskeibaar van die idee van 'n tekstuele doolhof. Om tot ' $n$ teks te behoort, beteken om sonder einde daar, sedert altyd, rond te dwaal. Dit wat ontdek kan word in hierdie dwaling, onreduseerbaar tot die weë van herinnering, is dat daar ' $n$ teks is wat buite die gesigsveld val (Derrida 1981: 203). Daar kan van teks tot teks beweeg word, maar sonder om ò ooit ' $n$ tuiste vir die self of iets buite die teks te vind. Dit wat die teks te lese gee, is presies die moontlikheid van hierdie dwaling. Die tekstualiteit van die teks aanvaar 'n supplement van Unheimlichkeit wat nie reduseerbaar is tot enige vorm van hermeneutiese intimiteit nie.

... dissemination ... can never become an originary, central, or ultimate signified, the place proper to truth. On the contrary, dissemination represents the affirmation of this non-origin, the remarkable empty locus of a hundred blanks no meaning can be ascribed to, in which mark supplements and substitution games are multiplied ad infinitum (Derrida 1981: 268 noot).

Dit wat uit hierdie opposisie behou moet word, is veral die kontrastering van polisemie en disseminasie.

If there is thus no thematic unity or overall meaning to reappropriate beyond the textual instances, no total message located in some imaginary order, intentionality, or lived experience, then the text is no longer the expression or representation ... of any truth that would come to diffract or assemble itself in the polysemy of literature. It is this hermeneutic concept of polysemy that must be replaced by dissemination (Derrida 1981: 262).

Al die ander karaktertrekke van die teks wat Derrida erken, kan hulself rondom hierdie fundamentele opposisie organiseer.

Maar daar moet ook gevra word: Op watter wyse kan Mallarmé 
gesien word as eksemplaries van ' $n$ algemene teorie van die teks. Gaan dit nie eerder om 'n grensgeval nie? Derrida bevraagteken die legitimiteit van sodanige vraag. Daar word nogtans voortgegaan om die vraag te stel. Anders gestel, gaan dit om die herondersoek van die verhouding tussen algemene skryfhandeling en spesifieke literêre genres? Derrida (1981: 243) erken wel die volgende:

All the 'genres' of this generalised writing, including Fable, which actually tells a story, are distinguished by trace effects whose structure is in each case original (Derrida 1981: 243).

Maar terselfdertyd bevestig hy dat daar ' $n$ uitruiling van 'genres' plaasvind volgens 'die oneindige sirkulasie van die skripturele metafoor' (Derrida 1981: 244) wat juis ook sonder om enigiets te toon, luister aan hierdie uitruilende skakeling verleen.

Die hermeneutiese leeshandeling is georganiseer rondom die woord en rondom die polisemie. Sodanige lesing is onbevredigend as dit te staan kom voor die Mallarmé-teks wat Derrida lees. En die Derrideaanse kritiek op tematisme is in laaste instansie gerig teen die oor-evaluasie van die woord.

Thematicism necessarily leaves out of account the formal, phonic, or graphic 'affinities' that do not have the shape of a word, the calm unity of the verbal sign (Derrida 1981: 225).

In die geval van Mallarmé oortuig die demonstrasie op 'n baie effektiewe wyse. Selfs wanneer die poësie van Mallarmé gerig is op 'die algehele nuwe woord wat vreemd is aan die taal' (Derrida 1981: 256), is Derrida reg wanneer hy aantoon dat hierdie nuwe woord ook weer terugkeer na die taal en daarmee herkomponeer volgens nuwe netwerke van verskil en 'nie 'n meester-woord word met die finaal gewaarborgde integriteit van sin of waarheid nie'.

\section{DIE OPSKORTING VAN DIE OUTEUR}

Hoe kan die probleem van die teks se outeur vanuit die gesigspunt van die metodologie van interpretasie gestel word? Vir die romantiese hermeneutiek is die outeur die houer of die bewaarder van sin, byna die bevrugter of verwekker daarvan. Interpretasie is wesenlik ' $n$ reproduktiewe handeling: Die wording van die werk moet herverwesenlik word deur 'n soortgelyke interpretasie. Hierdie romantiese opvatting van interpretasie is verbind aan die teorie van die teks as ekspressie. 
Die vraag na die outeur is onskeibaar van dié van die oorspronklike bestemming: Tot watter mate is dit nodig om terug te keer na die oorspronklike outeur en die oorspronklike bestemming ten einde ' $n$ teks te verstaan?

Derrida het sekere redes waarom hy die outeur wantrou: Die outeur is altyd die eienaar van 'n tekstuele ousia (synde) en (dit is 'n nuwe feit met betrekking tot die hermeneutiese probleem) die diktator van sin wat sy gesegde afdwing soos die regspleger sy wil.

Hier is die rede waarom die opskorting van die outeur nie aangekondig word in die hermeneutiese bevoorregting van 'n gelyktydigheid van 'n soort ewige teenwoordigheid van sin, wat onttrek is aan die besoekinge van tydelikheid nie, maar in die 'spesifieke temporaliteit van die teks'. Dit is wat Derrida aandui deur die renaissance van Valéry na vore te bring:

He thought that it - the possibility for a text to yield (itself): several times and several lives - calculates (itself). I am saying it calculates itself: such a ruse cannot be machinated in the brain of an author, quite simply, except if he is situated like a spider who is somewhat lost in a corner of its web, off to the side. The web very quickly becomes indifferent to the animal-source, who might very well die without even having understood what had happened. Long afterward, other animals again will come to be caught in its threads, speculating, in order to get out, on the first meaning of a weave, that is of a textual trap whose economy can always be abandoned to itself. This is called writing (Derrida 1982: 278).

Hierdie luisterryke teks, wat byna as ' $n$ verklaring van beginsel gelees kan word, spreek die vraag van die outeur aan in terme wat sekerlik nie tot die hermeneutiek behoort nie. Die band met die teorie van die teks is evident deur die metafoor van die teks en die verwysing na die spinnekop (web-spinner) - 'n beeld wat nie vreemd is aan Nietzsche en Lautrêamont nie. Maar meer as bloot 'n verklaring van beginsel moet die funksionering in die interpretasie-praktyk self geplaas word. Die meer betekenisvolle gedeelte in hierdie verband is Derrida (1977: 203-204) se analise van die 'geval' Rousseau.

Dit handel oor 'n soort voorwoord tot die lesing van l'Essai sur l'Origine des langues wat ten doel het om te toon dat die teoretiese oorwegings van Rousseau gelees moet word saam met die literẽre ervaring 
van die outeur. Om die vraag in hierdie terme te stel, verplig ons duidelik daartoe 'om onder die titel skriftuur die ervaring en teorie van Rousseau oor skriftuur te dink' (Derrida 1977: 207). Die Derrideaanse lesing het belang daarby om die debat in die mees problematiese gebied binne te voer. Die teks waaroor dit gaan, behoort tot die genre van die Confessiones waar die terugkeer na sekere psigologiserende kategorieë byna onvermydelik blyk te wees. Dit is 'n bladsy van die Confessiones wat gelees moet word 'soos 'n teks en nie soos ' $n$ dokument nie' (Derrida 1977: 214).

Die probleem van die teks is om presies die verhouding tussen die ekonomie van die denke van Rousseau en sy literêre ervaring te bepaal. Om sekere tekste in die Confessiones te verstaan, moet rekening gehou word met Jean-Jacques. Maar wie is Jean-Jacques? Dit is hier waar Derrida die term supplement invoer. Hierdie woord dui allereers op 'n bevoorregte term in die taal van Rousseau (van sy linguistiese kode), die gebruik wat daarvan gemaak word in sy geskrifte en wat ontsnap aan die kategorie van die taal, soos aan dié van die diskoers (Derrida 1977: 214). Die woord dui verder ook op en die 'logika' van die verhouding tussen die leer van Jean-Jacques en die teks van Rousseau. In die lang metodologiese opmerking wat die lesing van hierdie teks vergesel, lyk dit asof Derrida twee versoekinge wil vermy: Die versoeking van 'n transendente lesing wat die teks te bowe gaan in die rigting van iets anders as die teks self, ' $n$ laaste of hoogste verwysing of ' $n$ betekenis (Derrida 1977: 227) en 'n regressiewe lesing wat wentel om die psigobiografiese leefwêreld van Jean-Jacques. Hierdie laaste versoeking is hier van belang: Dit neem die konkrete vorm van 'n psigoanalitiese leeswyse aan! Dat die teks van die Confessiones ontleen word aan hierdie tipe lesing is duidelik; maar wat Derrida met reg onderstreep, is die verskil tussen die normale analitiese situasie en die ontmoeting met 'n teks. Die psigoanalise sal altyd in die versoeking wees om die teks as 'n simptoom tussen ander simptome te sien, of anders gestel, steeds as 'n uitdrukking van ' $n$ individuele psige te sien en hom sodoende blind hou vir die weefsel self, vir die spesifieke tekstuur dus van die literêre simptoom (Derrida 1977: 228). Gekonfronteer met hierdie lesing onderstreep Derrida twee punte waarvan die teoretiese implikasies moeilik oorskat kan word: Eerstens, die psigoanalise bevind homself eweneens binne die teks, dus 'die psigoanalitiese teorie self is vir ons ' $n$ totaliteit van tekste wat tot ons kultuur en geskiedenis behoort; op 'n sekere manier is ons in die geskiedenis van die psigoanalise soos ons in die teks van Rousseau is' (Derrida 1977: 230). En dan, en dit is belangrik, 
die 'lewe' of die 'leefwêreld' (Erlebnis) ontsnap nie aan die algemene problematiek van die geskrif nie, omdat die lewe van Jean-Jacques self soos 'n teks gelees word:

It is so little a matter of looking for a truth signified by these writings (metaphysical or psychological truth: Jean-Jacques's life behind his work) that if the texts that interest us mean something, it is the engagement and the appurtenance that encompass existence and writing in the same tissue, the same text. The same is here called supplement, another name for différance (Derrida 1977: 215; vgl 1982: 1-27).

Indien die outeur, volgens Derrida, 'agter' die teks verdwyn, is dit nie omdat hy uitgewis word in die naam van die boodskap wat hy lewer nie, maar omdat daar nie meer ' $n$ wyse is om hom te onderskei van die teks wat hy skrywe en wat nie deur hom oorheers word nie. Net soos die teorie van die teks wat Derrida voorstel, die polisemie as teorie van die meester-woord ondergrawe, so verdwyn die outeur as die leier (archonte) van die diskoers, dit wil sê as diktator. Maar die grammatologiese perspektief lei nie tot 'n waardebepaling van die transparensie van ' $n$ boodskap nie. Al hierdie bevestiginge het sin slegs binne die horison van 'n problematiek van geskrif en van teks. Dit ontwikkel van die kant van die taal en van die kode (Derrida 1977: 214). Vanuit hierdie gesigspunt word mens noodwendig gelei om 'n nuwe problematiek van die afdeling découpage van tekste uit te werk (Derrida 1981: 231). Effektiewelik laat die tradisionele hermeneutiek die outeur toe om homself vry te stel van hierdie problematiek: 'n Mens was in die teenwoordigheid van 'n teks, elke keer wanneer dit moontlik was om die teks aan ' $n$ bepaalde outeur toe te skrywe. Vanaf die oomblik dat die beginsel van die outeur gelikwideer word, is die eenheid van die werk nie meer gewaarborg deur die singulariteit van 'n funderende ervaring nie. Is dit dan voldoende om hom te vervang met die singulariteit van die gelewerde boodskp? Gadamer is nie ver van hierdie hipotese verwyder nie. Maar die belang van die protokolle van lesings wat Derrida aan ons voorskrywe, is om te toon hoe hierdie beginsel probleme oplewer: Sodra daar aandag gegee word aan die tekstuur van die teks is dit moeilik om te sê waar die teks ophou en waar die outeur begin (Derrida 1981: 231). Die lesing van Plato lei na die Egiptiese mites, en baie verder na die geskiedenis van die Westerse metafisika, met behulp van 'n logika van die supplement wat nie sy effekte beperk tot die 
enkele tekorte wat voorgestel word om te analiseer nie. Elke keer as daar probeer word om iets onreduseerbaar Rousseauisties te omvat, word daar terselfdertyd 'n massa (steeds goed ingelig) van wortels, van gebied en van sedimente van allerlei soort weggeneem (Derrida 1977: 231).

Wat deur hierdie analise van Derrida getoon word, is dat die alternatief outeur/boodskap miskien te beperkend is. Selfs al word dit gehandhaaf dat die outeur nie essensieel is vir die verstaan van ' $n$ teks nie (anders gestel, dat die teks iets anders is as Erlebnisausdrucke), kan daar nie te vinnig ontvlug word na die gesegde van die teks nie.

\section{DIE PROBLEEM VAN REFERENSIE}

Die vraag na die teks moet nog 'n keer opgeneem word, hierdie keer met die oog op die ander uiterste, naamlik dié een waar die teks klaarblyklik na iets wys wat as sy verwysing beskou kan word, dit wil sê dít waaroor gepraat word. Die hermeneutiek gee die versekering dat daar ' $n$ waarheid van die werk' is, dat die teks sin het, of die waarheid praat.

Hierdie hermeneutiese versekering word geskud deur die problematiek van die verwysing (of van die pré-teks), soos Derrida, op die grondslag van Mallarmé, dit uitwerk, en meer spesifiek deur die fiksie wat Mallarmé se teks aanbied. Soos in die geval van Rousseau waar die vraag van die outeur gestel was op die basis van 'n teenvoorbeeld (naamlik 'n snit uit die Confessiones, 'n genre wat besonder self-impliserend is), stel Derrida hier die vraag aangaande ' $n$ bevoorregte teks: Mimique van Mallarmé, dit wil sê in hierdie geval 'n teks wat lyk asof hy juis die vraag na verwysing afdwing, asof hy dit voorskryf (Derrida 1981: 225). Die studie van hierdie teks toon dat die vraag na sy verwysing, terwyl hy homself tot in die oneindige dissemineer, geheel en al sy sin verloor. Daar sal altyd 'n verwysing gevind word, maar hierdie verwysing is ' $n$ ander teks wat op sy beurt weer self na 'n derde teks verwys en so aan:

A writing that refers back only to itself carries us at the same time, indefinitely and systematically, to some other writing (Derrida 1981: 202).

Dit beteken dat daar, ten minste in die geval van Mallarmé, op 'n paradoksale wyse gepraat moet word van 'n verwysingstruktuur in die 
afwesigheid van 'n verwysing (Derrida 1981: 211). Hierdie struktuur noem Derrida vervreemde verwysing:

In folding it back upon itself, the text thus parts with reference, spreads it like a V, a gap, that pivot on its point, a dancer, a flower, or Idea (Derrida 1981: 239).

In hierdie teks word die figuur van die danseres van Mallarmé en wat Derrida erken as die beweging van die pirouette, beskrywe:

Each piroutte is then, in its twirling, only the mark of another pirouette, totally other and yet the same (Derrida 1981: 241).

Om die referensie eenkant toe te skuiwe, beteken daarom nie dat dit eenvoudig eenkant geplaas word nie, dit wil sê afgeskaf word nie. Die eenkantplasing van die verwysing of referensie sou neerkom op die afskaffing van die verwysing, aangesien die referensie daarmee terugbuig na homself en dit beteken niks anders nie as die ruimtelikheid van die skriftuur. Hierdie struktuur kenmerk homself by Mallarmé deur ' $n$ komplekse woordeskat wat Derrida sorgvuldig analiseer aan die hand van die Mallarméaanse idee van sinspeling.

In this perpetual allusion being performed in the background of the entre that has no ground, one can never know what the allusion alludes to, unless it is to itself in the process of alluding, weaving its hymen and manufacturing its text. Wherein allusion becomes a game conforming only to its own formal rules. As its name indicates, allusion plays. But that this play should in the last instance be independent of truth does not mean that it is false, an error, appearance, or illusion. Mallarmé writes 'allusion', not 'illusion'. Allusion, or 'suggestion' as Mallarmé says elsewhere, is indeed that operation we are here by analogy calling undecidable. An undecidable proposition as Gódell demonstrated in 1931, is a proposition which, given a system of axioms governing a multiplicity, is neither an analytical nor deductive consequence of those axioms, nor in contradiction with them, neither true nor false with respect to those axioms (Derrida 1981: 219).

Die Mallarméaanse sinspeling ontdek sodoende 'n literêre organisasie waar daar van die teks gesê word dat dit ver buite sig geraak het (Derrida 1981: 203), dus dat dit 'n eindelose netwerk van betekenaars is. 
Disseminasie is onversoenbaar met die stilstand voor 'n verwysing, veral voor 'die bevoorregte referensie wat die syn voorstel'.

What is produced is an absolute extension of the concepts of writing-reading, of text, of hymen, to the point where nothing of what is can lie beyond them (Derrida 1981: 223).

Dit wat hier aangekondig word as tekstuele effek, is duidelik afkomstig van die globale ekonomie van die différance vir sover die différance alle ontologieë dwarsboom.

Tot watter mate is hierdie analise wat rus op die 'literêre ervaring' van Mallarmé veralgemeenbaar? Vir Derrida is die vervreemde referensie konstitutief vir die skriftuur as sodanig, hoewel dit so is dat hierdie struktuur beter genoteer kan word in ' $n$ teks van Mallarmé as in ' $n$ ander (Derrida 1981: 242).

Die afwysing van die referensie is duidelik onversoenbaar met die hermeneutiese woordeskat van manifestasie: Dit waarop teks volgens die hermeneutiek wys, is altyd ' $n$ sin, en boonop ' $n$ teenwoordige sin. Die referensie stel 'n waarheid, of ' $n$ wêreld, of 'n god teenwoordig. Die teks praat nie van homself nie, maar van iets anders. Die struktuur van die verwysing binne die hermeneutiek is wesenlik representatief. Volgens Derrida representeer die referensie nie meer nie, dit illustreer eenvoudig. Hierdie teenstelling tussen representasie en illustrasie moet verdiep word. Hierdie begrippe-paar is nie onbekend aan die moderne literatuur-teoretici nie (Todorov).

\section{HERINTERPRETASIE VAN INTERPRETASIE}

Die ondersoek van die voorafgaande drie paragrawe het gerig gebly op 'n presiese taak wat aan die begin gedefinieer is: Wat is interpretasie? Hoe moet die werk of taak van interpretasie konkreet gedefinieer word? Die oorweging ten opsigte van die status van die teks, die verduistering van die outeur en die probleem van verwysing, inisieer alreeds so 'n definisie. Nou moet dit direk uitgespel word. Dit is slegs moontlik as daar rekening gehou word met 'n vierde element wat tot dusver nog nie getematiseer is nie: die leser self. Die vraag na interpretasie is in der waarheid, in die laaste instansie, onskeibaar van die vraag na die leeshandeling indien dit waar is wat Derrida onderstreep, naamlik dat 'die vraag van die teks vir diegene is wat dit lees'. Watter tipe verhouding van leser tot teks veronderstel so ' $n$ formule? 
Volgens die hermeneutiese interpretasie van hierdie verhouding is dit noodsaaklik om terug te keer na die term 'behoort' soos tevore gedefinieer. Die hermeneutiese behoort is onskeibaar van die privilege van te luister. Om te lees is allereers om 'n teks te hoor. Dit is slegs moontlik wanneer die teks self as 'n virtuele diskoers gesien word. Hiermee kom die fonosentristiese gedagte duidelik na vore. Die lesing is passief; die leser gee die woord aan die teks. Die sin van die teks bestaan op geen ander manier nie as in die operasie van interpretasie. In hierdie komplekse verhouding van die sogenaamde hermeneutiese sirkel is die terme behoort - toepassing - toeëiening - selfbegrip, sentraal. Hierdie produksie van sin verloop nie sonder eksplisiete verwysing na die subjek van interpretasie nie.

Hierdie agtergrond maak dit duidelik waarvan Derrida se interpretasieteorie afskeid neem. Dis 'n teorie wat eksplisiet gemaak is onder die invloed van Nietzsche, die meester van agterdog: 'soos Nietzsche interpretasie herinterpreteer' (Derrida 1982: 362). Die swak speler van die filosofie, is ook die man van spel. Die beoefening van agterdog, op die vlak van interpretasie, is niks anders nie as die keersy van die filosofiese gebaar van een wat filosofeer 'met 'n hamer'. 'n Hamer wat letterlik die ore van die hermeneutiek bestook (of op die ore rammel) (Derrida 1982: IV; XII) deurdat dit die dubbele fundamentele vooronderstelling van die hermeneutiek ruïneer: Die prioriteit van die akoestiese in die term behoort en - sy presiese korrespondent op die vlak van houdinge - die hermeneutiese eerlikheid.

Kom ons kyk na hierdie dubbele artikulasie op die vlak van die grammatologie:

Sou daar 'n semantiese en ontologiese bevoorregting van tekste wees wat die objek van interpretasie vorm? Gadamer tematiseer hierdie privilege onder die titel 'Vorgriff der Volkommenheit'. Die grammatologiese opvatting van die teks is onversoenbaar met ' $n$ privilege wat uitgedruk word in die metafisiese woordeskat van volkomenhede. Indien daar iets is wat weerklank vind in ' $n$ teks, is dit nie een of ander volkomenheid nie, maar 'die gepreokkupeerde dissimulasie van die tekstuur van die teks self'. Dit is hierdie dissimulasie wat interpretasie moontlik maak; interpretasie wat ook kritiek is vir sover dit die betekenisgewende struktuur van die teks wil produseer (Derrida 1977: 158).

Daar is baie duidelik ' $n$ ooreenkoms tussen die opvatting van die teks as 'produksie van die verskil' en die bepaling van interpretasie as produksie. Maar wat beteken 'produseer' hier, wat is die draagwydte 
van hierdie metafoor, wat in die oë van Derrida lyk asof dit des te beter die werk van die leeshandeling aandui?

$\mathrm{Om}$ ' $\mathrm{n}$ betekenende struktuur te produseer, is in die eerste plek iets heel anders as om sin in ' $n$ betroubare kommentaar te reproduseer, maar dit beteken veel eerder om 'n leesmoontlikheid te open.

To produce this signifying structure obviously cannot consist of reproducing, by the effaced and respectful doubling of commentary, the conscious, voluntary, intentional relationship that the writer institutes in his exchanges with the history to which he belongs thanks to the element of language. This moment of doubling commentary should no doubt have its place in a critical reading. To recognize and respect all its classical exigencies is not easy and requires all the instruments of traditional criticism. Without this recognition and this respect, critical production would risk developing in any direction at all and authorize itself to say almost anything. But this indispensable guardrail has always only protected, it has never opened, a reading (Derrida 1977: 158).

Die verskil tussen die twee leeswyses kom na vore wanneer die vraag gestel word: Wat beteken oop in albei gevalle? Vir die hermeneutiek dit is die funksie van die hermeneutiese sirkel - gaan dit oor die oopstelling vir sin, terwyl die grammatologie moet kyk na (in 'n gebaar wat meer as een keer die allure neem van 'n ware kragtoer) die barste en krake van die teks, dus dít wat die immanensie van sin weerstaan. Die verskil word duidelik met behulp van twee Duitse woorde wat 'opening' beteken: Offenheit, die opening van 'n wêreld as iets spesifiek; Öfnung, die gaping van 'n ruimte as 'n onbeperkte oopte. Derrida (1978: 292-293) onderskei soos volg tussen die twee interpretasies van interpretasie:

There are thus two interpretations of interpretation, of structure, of sign, of play. The one seeks to decipher, dreams of deciphering a truth or an origin which escapes play and the order of the sign, and which lives the necessity of interpretation as an exile. The other, which is no longer turned toward the origin, affirms play and tries to pass beyond man and humanism, the name of man being the name of that being who, throughout the history of metaphysics or of ontotheology - in other words, throughout his entire history - has dreamed of full presence, the reassuring foundation, the origin and the end of play. The second interpretation 
of interpretation, to which Nietzsche pointed the way, does not seek in ethnography, as Lévi-Strauss does, the 'inspiration of a new humanism' (again citing the Introduction to the work of Marcel Mauss).

There are more than enough indications today to suggest we might perceive that these two interpretations of interpretation which are absolutely irreconcilable even if we live them simultaneously and reconcile them in an obscure economy - together share the field which we call, in such a problematic fashion, the social sciences.

Die moontlikheid om die teks te oorskry in die rigting van dasein, en die opening van die wêreld word afgewys in die grammatologiese interpretasie: 'Daar is niks buite die teks nie' (Derrida 1977: 158) en hiermee word die afwesigheid van die referent, van die transendentale betekenaar, bevestig. Die nie-oorskrydende lesing, die grammatologiese lesing, geheel en al gerig op die tekstualiteit van die teks, is 'n aggressiewe lesing. Hierdie aggressiwiteit antwoord op verskillende maniere afhangende van die struktuur van die gelese teks. Hy toon homself die mees aggressiewe voor die filosofiese tekste omdat hulle die meeste gerig is op die uitwissing van hul eie tekstualiteit: ... the philosophical text, although it is in fact always written, includes, precisely as its philosophical specificity the project of effacing itself in the face of the signified content which it transports and in general teaches. Reading should be aware of this project even if, in the last analysis, it intends to expose the project's failure (Derrida 1977: 160).

Hierdie lesing is noodwendig gerig op die literêre simptoom as sodanig: ... the primordial and indispensable phase, in fact and in principle, of the development of this problematic, consists in questioning the internal structure of these texts as symptoms (Derrida 1977: 99).

Dit is duidelik dat hierdie bepaling van interpretasie as simptomale lesing ambigueus kan voorkom vir sover dit byna noodwendig uitnooi tot 'n oorskryding in die rigting van die psigobiografiese, volgens die voorbeeld van baie psigoanalitiese lesings. Sulke lesings verstaan die spesifieke tekstuur van die literêre simptoom op 'n sistematiese wyse verkeerd; om te praat van 'n simptoom kom dus hier neer op die erkenning dat dit in beginsel onmoontlik is om deur interpretasie of kommentaar, die 'die betekende' van 'betekenaar' te skei, en om sodoende die skryfhandeling deur die skriftuur, wat steeds ook lesing is, te vernietig (Derrida 1977: 159). Die simptomale lesing open homself na 
die 'diepte' van die teks wat niks met semantiese densiteit te doen het nie. Die 'diepte' van die teks wat die hermeneutiek ondersoek, is vir die grammatologie 'tegelykertyd niks en oneindig' (Derrida 1981: 357).

Die 'geologiese' metafoor is duidelik nie so onskuldig nie: Die leeswerk is nòg op dít wat openbaar is, gerig, nòg op sin vir sover dit homself manifesteer, maar gerig op iets verborge, op die strukture wat aan die lig gebring moet word in ' $n$ werk wat homself bereken. Interpretasie, vir sover dit gerig is op tekstualiteit, is 'n kwasi-matematiese operasie, wat verwesenlik word deur middel van sorgvuldige leesprotokolle waarvan die spoor herken word by Plato, Rousseau en Mallarmé.

Ons het hier te doen gekry met twee leeservaringe: Die hermeneutiek wat die ontdekking is dat ons alreeds binne die hermeneutiese sirkel is; die grammatologie wat die sekerlik verwarrende, verbysterende ontdekking is dat ons steeds nog nie weet hoe om te lees nie. Om hierdie rede is dit so ter sake dat Nietzsche, 'die eerste filosoof van die geskrif', skrywe 'vir almal en vir niemand'.

Terwyl dit ingeskrywe is in die algemene ekonomie van différance, is interpretasie soos Derrida dit verstaan, 'n tweedeling: As swak speler, is die grammatologie ook oneerlik. Soos die hermeneutiese eerlikheid wat hom verlaat op die betekenis van die teks, situeer hierdie kategorie homself aan die ander kant van goed en kwaad. Dit handel nie direk vanweë 'n etiese houding waarvolgens op ' $n$ bepaalde wyse geoordeel word nie. Tweedeling beteken 'n ambigueuse houding met betrekking tot tekste wat alleen toelaat dat hul skriftelikheid genoteer word. Net soos ' $n$ mens met twee hande skrywe, is dit ook nodig om geoefen te word om met twee hande te lees. Die grammatologie in sy geheel reflekteer hierdie dubbele gebaar. 'n Gebaar wat noodsaaklikerwys kompleks en oormatig is, buitensporig ook in verhouding tot die wentelbaan van die hermeneutiese sirkel:

The excess - but can we still call it that? - is only a certain displacement of the series. And a certain folding back (repli) - which will later be called a re-mark - of opposition within the series, or even within its dialectic. We cannot qualify it, name it, comprehend it under a simple concept without immediately being off the mark. Such a functional displacement, which concerns differences (and, as we shall see, 'simulacra') more than any conceptual identities signified, is a real and necessary challenge. It writes itself. One must therefore begin by reading it (Derrida 1981: 104). 
Hierdie herinterpretasie van interpretasie is nodig. Die spel van die skryfhandeling wat die grammatologiese lesing begin noteer, doen afstand van die subjek, hetsy die subjek as meester, hetsy die subjek as onderworpene. Daar is net so min 'n lesende subjek as wat daar 'n skrywende subjek is. Interpretasie: 'n Ander skryfhandeling wat baie goed klaarkom sonder die subjek en terwyl dit gedoen word, toelaat dat hy sy tyd verwyl op ' $n$ besonder aangename wyse met baie plesier:

The hesitation between writing as decentering and writing as an affirmation of play is infinite. This hesitation is part of play and links it to death. Hesitation occurs within a "who knows?" without subject or knowledge (Derrida 1978: 297).

Hoe word hierdie huiwering en onsekerheid uitgewis deur ' $n$ metode? Dit sinspeel op niks anders nie as die doolhof van die denkweg wat die denke uitdaag om hom aan te durf. Die vertrekpunt van die weg is daar waar ons is, dwalend in die doolhof van die teks (Derrida 1977: 162). Denke oor ' $n$ teks en binne die ruimtelikheid van 'n teks, in die lig van die outonome produktiwiteit van die teks, beteken om weg te breek uit die rigiede omraminge van metodes, ook van die hermeneutiese metode. Daar kom beweegruimte wat die leser vrymaak om aanvaarde filosofies-metafisiese voorstellinge van God, waarheid, gesag, subjek, sonde, sin, ensovoorts te bevraagteken, te herdink en te herbeskrywe. Binne praktiese religieuse verband kom dit neer op 'n radikale hersiening van wat normaalweg beskou word as die sogenaamde 'wese' van God (hy word die ondenkbare en onsigbare), die aard van die ewige waarhede (dit word voorlopig en gepaar met onwaarheid, leuen en distorsie), die rol van die pastoraat (dit word die soeke en denke van gelyke lotgenote eerder as die optrede van arrogante regeerders, wegwysers, beoordelaars en beterweters). Daar word doodgewoon, danksy die dekonstruktiewe leeshandeling, anders gedink oor gode, mense, waarhede, lewe en wêreld - minder verslawend, inperkend, verknegtend, ernstig en streng, maar veral meer vry, oop, nuut, opwindend, jubelend en ... speels.

Daar is groot waardering teenoor diegene - en daar is min van hulle wat dit pertinent doen - wat jou bekendstel aan die denke as weg, en aan die weg van die denke. Indien hierdie denke opgeneem word en hierdie weg betree word, sou dit jammer wees as dit sou neerkom op die loop in ' $n$ uitgetrapte pad. Om bekendgestel te word aan ' $n$ denkweg beteken nie om in die spore van iemand te loop nie, maar altyd: om op die denkweg vorentoe te loop, om hom uiteindelik op jou eie te 
loop, om hom alleen te loop en veral te loop waar nog nie geloop is nie en te dink - as mens dit kan vermag - soos nog nie tevore gedink is nie. Die bekendsteller loop ' $n$ risiko indien hy sou verwag dat daar in sy voetspore gevolg moet word - dit sou dan geen denkweg meer wees nie, maar 'n leë gedagtelose nabootsing en dus geen denke nie. Sou dit die verwagting wees, sou dit geen bekendstelling aan die denkweg wees nie. Hiermee sou die reg om te dink en op 'n eie manier die denkweg (en dít is die menseweg) te betree, misken word. Indien dit nie die verwagting is nie, kan daar en word daar inderdaad in vryheid denkend en dankend vorentoe beweeg en verder gedink.

Weliswaar is dit ekonomies en strategies om die kortste pad te volg ten einde te verseker dat daar iewers aangeland word, ongeag waar. Die feit en die plek van aankoms is dan meer werd as blote ronddwaling. Selfs al is die bestemming nie die beste nie, is daar van die begin af die moontlikheid: om te arriveer, ongeag waar, is beter as om nie te arriveer nie. Hierdie versekering gee gewis iets te denke; maar daar is verdienste in om 'n oomblik tot stilstand te kom.

\section{Literatuurverwysings}

DERRIDA, J 1978. Writing and difference. Chicago: University of Chicago Press. (L'ecriture et la différence. Editions du Seuil, Paris - 1967.)

DERRIDA, J 1977. Of grammatology. Baltimore: Johns Hopkins University Press. (De la Grammatologie, Les Editions de Minuit, Paris - 1967.)

DERRIDA, J 1980. Positions. London: Athlone. Positions, Les Editions de Minuit, Paris 1972.

DERRIDA, J 1981. Dissemination. Chicago: University of Chicago Press. (La Dissémination, Editions du Seuil, Paris - 1972.)

DERRIDA, J 1982. Margins of philosophy. Sussex: Harvester. (Marges de la Philosophie, Les Editions de Minuit, Paris - 1972.)

DERRIDA, J 1983. Le langue et le discours de la méthode. Recherches sur La Philosophie et Le Langage 3, 35-51.

DERRIDA, J 1984. Deconstruction and the Other, in Kearny, R, Dialogues with contemporary Continental thinkers. Manchester: Manchester University Press.

DERRIDA, J 1986. Schibboleth, pour Paul Celan. Éditions Galilée. Paris.

HEIDEGGER, M 1985. The want of Holy Names. Man and World, 18/3, 261-267. 